toče prevladuje gliva Diplodia pinea (Desm.) J. Kickx f. (sin. Sphaeropsis sapinea (Fr.) Dyko \& B. Sutton), povzročiteljica bolezni borov z imenom sušica najmlajših borovih poganjkov. Gliva povzroča odmiranje skorje, ki se širi okoli rane in povzroči odmiranje vej; gliva se lahko tudi razraste $\mathrm{v}$ deblo in povzroči odmiranje celega drevesa in modrenje lesa (Jurc, 2007). Bolezen je splošno razširjena $\mathrm{v}$ okolici Ljubljane, povzroča odmiranje mladih poganjkov in vej predvsem črnega bora, ob močnem sušnem stresu pa tudi odmiranje dreves. Na Golovcu pri Ljubljani so se leta 2001 sušila odrasla drevesa rdečega bora (Jurc D. in Jurc M., 2002). Zajedavska gliva Diplodia pinea je splošno razširjena tudi po vsej Sloveniji, okuži in uniči predvsem zaradi suše oslabele bore in v zadnjih letih povzroča zlasti obsežno sušenje krošenj črnih borov na Krasu.

Lastnikom gozdov na poškodovanem območju smo svetovali posek borov s poškodovanostjo krošnje več kot 80 \%, ker bodo zaradi okužbe z glivo odmrla. Ker obstaja verjetnost, da se na poškodovanih borih in dru- gih iglavcih namnožijo podlubniki, je potrebno redno spremljanje stanja poškodovanega gozda. Na obravnavanem območju so bile že poleti 2010 evidentirane posamezne s podlubniki napadene smreke.

\section{Viri}

Jurc D., Jurc M. 2001. Rdeči bor (Pinus sylvestris) se na Golovcu suši zaradi sušice najmlajših borovih poganjkov (Sphaeropsis sapinea). Gozdarski inštitut Slovenije in Gozdarski oddelek BF, Poročevalska, diagnostična in prognostična služba za varstvo gozdov, 3 str.

Jurc D. 2007. Bori - Pinus spp.: bolezni poganjkov, vej in debla: Sphaeropsis sapinea, Cenangium ferruginosum, Sydowia polyspora. Gozdarski vestnik, Ljubljana, 65, 1: [129-144], 25-40

1Zavod za gozdove Slovenije, Večna pot 2, 1000 Ljubljana; 'Zavod za gozdove Slovenije, Krajevna enota Grosuplje, Taborska n.n., 1290 Grosuplje; ${ }^{3}$ Gozdarski inštitut Slovenije, Večna pot 2, 1000 Ljubljana *marija.kolsek@zgs.gov.si

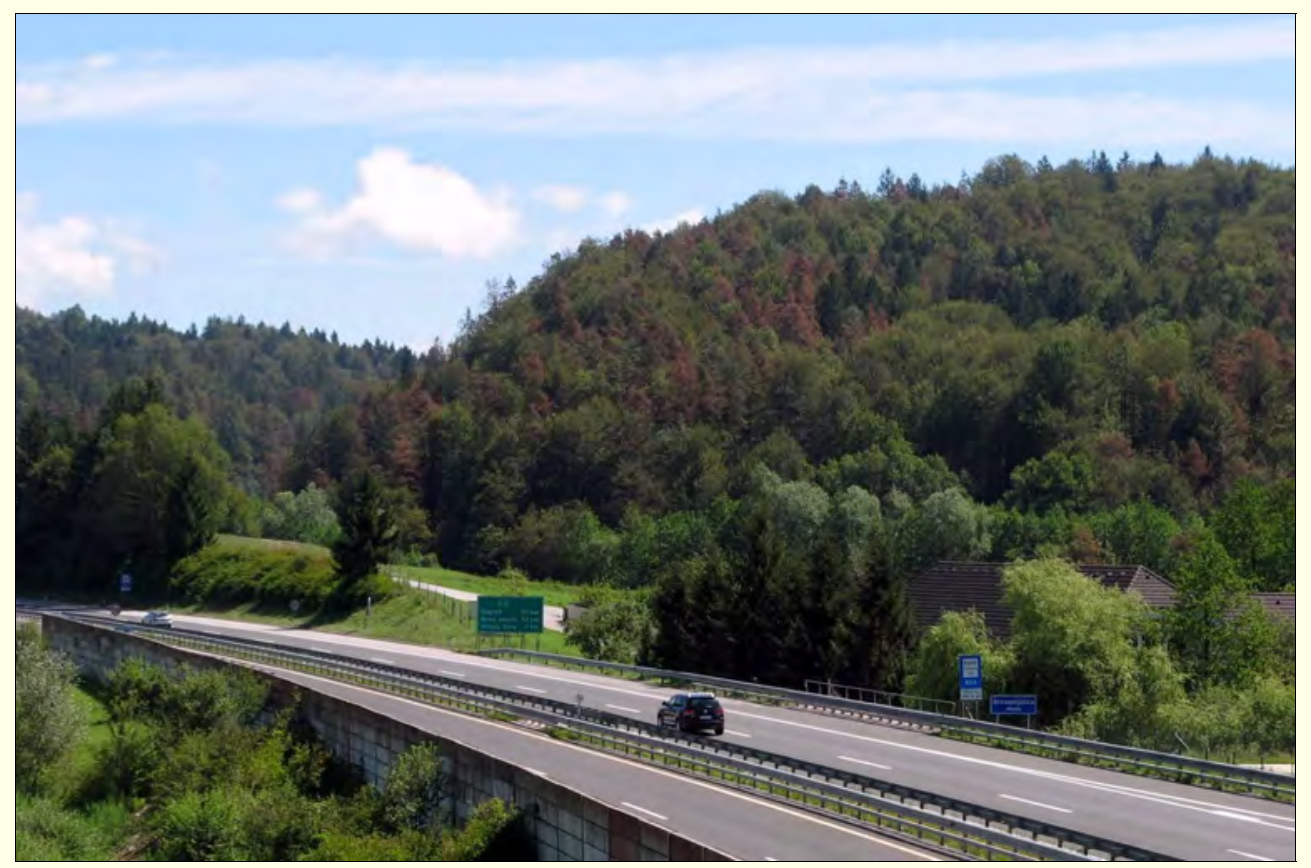

Slika 1: Sušenje borov ob avtocesti pri Grosuplju je posledica toče in naknadnih okužb z glivami (foto: Barbara Piškur, Gozdarski inštitut Slovenije)

\title{
Ukrepi proti namnožitvi zapredkaric (Cephalcia spp.) na Riflovem vrhu pri Prevaljah v letu 2010
}

\section{Gorazd MLINŠEK ${ }^{1 *}$, Janko MIKELN ${ }^{2}$, Franjo ŠTERN $^{2}$, Marija KOLŠEK $^{3}$}

V letu 2009 so bile v Sloveniji prvič evidentirane poškodbe sestojev, ki so jih povzročile rastlinske ose zapredkarice iz rodu Cephalcia (Hymenoptera: Pamphiliidae). Predstavniki rodu Cephalcia, ki se avtohtono pojavljajo v Evropi, lahko ob večletnih namnožitvah povzročijo poškodbe na velikih površinah - defoliacije in posledično zaradi sečnje oslabelih dreves tudi večje ogolele površine. Poškodbe povzročajo ličinke z obje- danjem iglic zlasti na smreki in redkeje na drugih iglavcih. Prvo obvestilo o namnožitvi zapredkaric pri nas je v prispevku M. Jurc, G. Mlinšek: Zapredkarice (Cephalcia spp.) na vejah navadne smreke na Koroškem pri Prevaljah. Novice iz varstva gozdov št. 2, 2009, stran 12-13. V tem prispevku poročamo o ugotavljanju obsega poškodovanosti in o ukrepanju Zavoda za gozdove Slovenije. 
Namnožitev zapredkaric je bila ugotovljena v smrekovem sestoju v severnem delu Slovenije na nadmorski višini 600-800 m (na Riflovem vrhu pri Prevaljah). Ker je bila prisotnost poškodb krošenj smrek ugotovljena v začetku julija, je bilo prepozno, da bi lahko izvajali obsežnejše zatiralne ukrepe, zato smo v letu 2009 večjo pozornost namenili natančni določitvi območja namnožitve oziroma številčnosti zapredkaric. Zapredkarice so bile ugotovljene na 106 ha smrekovih sestojev. Na skoraj 4 ha so povzročile močne poškodbe (poškodovane nad 60 \% krošnje), na 60 ha so bile poškodbe majhne, na 42 ha so bile poškodbe neznatne. Poškodbe smrekovih sestojev so nastale zaradi obžiranja več vrst zapredkaric iz rodu Cephalcia.

$\mathrm{Na}$ podlagi ugotovljene velike številčnosti eonimf in/ali pronimf na $\mathrm{m}^{2}$ tal smo predvidevali močne poškodbe smrek v letu 2010. Številčnost osebkov je ponekod presegala 1.700 eonimf in/ali pronimf na $\mathrm{m}^{2}$ tal; škodljive defoliacije pa se po navedbah iz tujih raziskav začenjajo pri 20 osebkih predpupalnih oblik na $\mathrm{m}^{2}$ tal v spomladanskem času. Za leto 2010 smo izdelali načrt ukrepanja ob namnožitvi zapredkaric, v katerem smo poleg spremljanja namnožitve ter zatiralnih ukrepov določili tudi način obveščanja lastnikov gozdov in javnosti o pojavu zapredkaric in izvajanju potrebnih zatiralnih ukrepov. Ker se številčnost osebkov v tleh preko zime ni bistveno zmanjšala, smo spomladi 2010 zagotovili izvedbo zaščite 8.070 dreves pred pričakovanimi poškodbami na osrednjem območju namnožitve. Zaščita je bila izvedena $\mathrm{z}$ namestitvijo lepljivih trakov širine ca. $15 \mathrm{~cm} \mathrm{v}$ prsni višini debla, na katere je bilo s sprejem naneseno namensko lepilo za lovljenje žuželk. Na trakove naj bi se prilepile samice ose zapredkarice, ki plezajo po deblih v krošnje dreves, kamor odlagajo jajčeca. Izletavanje os zapredkaric iz tal smo spremljali z rumenimi ploščami in ugotovili prvo rojenje osebkov v drugi polovici aprila. Masovni ulov samic na nastavljenih trakovih smo pričakovali v maju, ven- dar ga ni bilo tudi ne v kasnejšem obdobju. Ulov osebkov na trakove je bil majhen. Opaziti ni bilo niti znatnih poškodb v krošnjah. S ponovnim ugotavljanjem številčnosti osebkov v tleh v poznem poletju smo ugotovili, da je veliko število predpupalnih oblik osic še vedno $\mathrm{v}$ tleh. To pomeni, da se bodo verjetno izlegle $\mathrm{v}$ večjem številu v letu 2011 in takrat lahko pričakujemo večje poškodbe smrek. Za ose zapredkarice je znano, da lahko dokončajo razvoj do odraslega osebka v različno dolgih obdobjih in tako od prehoda ličinke $\mathrm{v}$ tla preživijo $\mathrm{v}$ neaktivni obliki eonimfe ali pronimfe eno leto ali več (do tri ali celo do štiri leta). Na osnovi ponovnega štetja osebkov $\mathrm{v}$ tleh in ugotovitvi razvojnega stadija v zgodnjem spomladanskem obdobju 2011 bomo določili obseg zatiralnih ukrepov v letu 2011, s katerimi bomo zmanjšali populacijo zapredkaric in preprečili poškodbe smrek.

\section{Viri}

Evidenca gozdnogojitvenih in varstvenih del za leto 2010. Ljubljana: Zavod za gozdove Slovenije, 2010 (interni obrazci)

Jurc M. 2009. Predhodno poročilo o pojavu zapredkaric (Pamphiliidae: Cephalcia) na vejah navadne smreke na Koroškem. Skupina za varstvo gozdov in ekologijo prostoživečih živali Oddelek za gozdarstvo in obnovljive gozdne vire Biotehniške fakultete, Univerza v Ljubljani, Večna pot 83,1001 Ljubljana: 6 str.

Jurc M., Mlinšek G. 2009. Zapredkarice (Cephalcia spp.) na vejah navadne smreke na Koroškem pri Prevaljah. Ljubljana: Novice iz varstva gozdov, 2: 12-13

Načrt ukrepanja ob namnožitvi zapredkaric (Cephalcia spp.) na Riflovemu vrhu pri Prevaljah. Ljubljana: Zavod za gozdove Slovenije, 2009: 20 str.

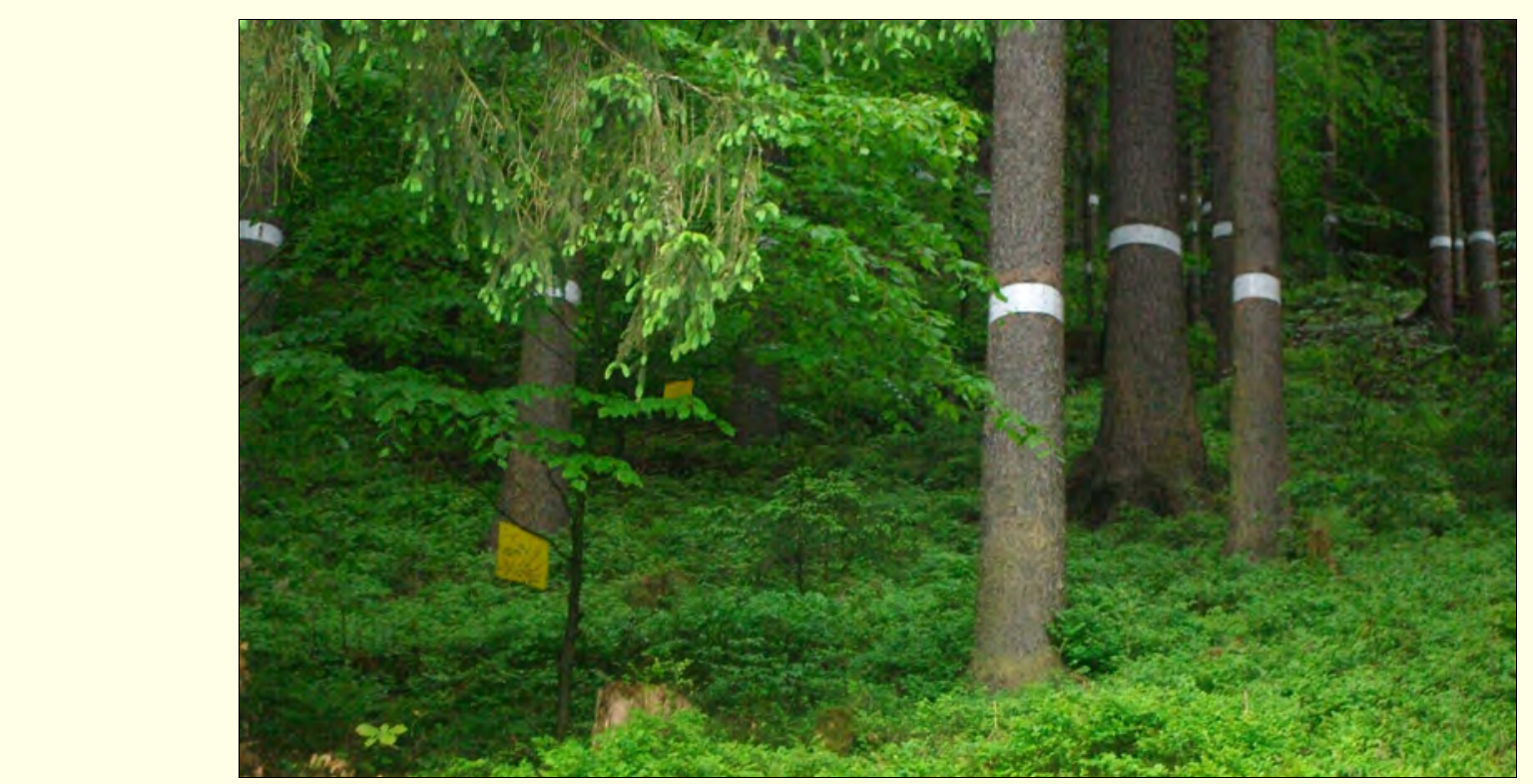

Zavod za gozdove Slovenije, Območna enota Slovenj Gradec, Vorančev trg 1, 2380 Slovenj Gradec; 2Zavod za gozdove Slovenije, Krajevna enota Prevalje, Trg 67, 2391 Prevalje; ${ }^{3 Z a v o d ~ z a ~ g o z d o v e ~ S l o v e n i j e, ~ V e c ̌ n a ~ p o t ~ 2, ~}$ 1000 Ljubljana *gorazd.mlinsek@zgs.gov.si

Slika 1: Zaščita dreves pred poškodbami zapredkaric je bila izvedena z namestitvijo lepljivih trakov širine cca 15 cm v prsni višini debla. Rojenje smo spremljali z rumenimi ploščami. 